\title{
20 Arboreal community of an Atlantic Forest hillside fragment in São Sebastião/SP
}

Ana Beatriz Carvalho Terra ${ }^{1}$

Gabriele Calle Bouças ${ }^{2}$

Marco Antônio Alves Garcia 3

\section{Abstract}

The urban expansion and the growth of economic activities related to tourism added to the port and maritime ones, resulted in the occupation of the Serra do Mar, in the municipality of São Sebastião/SP, increasing environmental degradation. The objective of the study was to evaluate the arboreal patterns in a 0.111 ha fragment around a 4.8 ha clearing in an area of Atlantic Forest in the city of São Sebastião (SP), allowing the revegetation plan to include native species observed in the region. The phytosociological analyses used the Point-Centered Quarter Method (PCQM), using 50 sampling points (30 in close areas, 10 in the forest edge, and 10 near one of the areas drains), with a minimum distance of 20 meters between them. The main variables analyzed were commercial height, diameter to chest height, successional category, and dispersion syndrome. Also, the number of individuals of each species was observed, as well as their basal area (G), absolute and relative density (DA and $D R$ ) and dominance (DoA and DoR), relative frequency (FR), and importance value (VI). The results indicate a higher proportion of non-pioneer species, with Guapira oppositte (Vell.) presenting the highest value of importance and density, and the Schizolobium parahyba (Vell.) Blake with the highest basal area. The survey data indicate the richness of species in the study area, serving as a basis for strategies for management and conservation of the environment. Phytosociological studies, although scarce, are important to support the analysis of preservation and the use of nature. Keywords: Degradation. Environment. Phytosociology. Recomposition.

\section{Introduction}

In Brazil, the economic growth by activities such as agriculture, livestock, mining, urbanization, and industrialization was not always related to the preservation of the environment (AZEVEDOSANTOS et al., 2017; SOARES-FILHO et al., 2014). Throughout its history, this continuous process of predatory interaction has led to a high amount of degraded areas and compromised provision of essential ecosystem services, as a major associated restoration liability (BRANCALION et al., 2016; REZENDE et al., 2018). Degradation levels vary between phytogeographic domains depending on the occupation history, with the Atlantic domain standing out concerning the others in association with the old occupation and its economic importance (BRANCALION et al. , 2016; JOLY et al., 2014; REZENDE et al., 2018).

\footnotetext{
1 Universidade José do Rosário Vellano (UNIFENAS). Doutoranda em Agricultura Sustentável. anabeatriz.terra@hotmail.com.

2 Universidade Federal do Paraná (UFPR). Engenheira Florestal. gabrielecalleb@gmail.com.

3 Universidade Federal de Alfenas (UNIFAL). Professor Doutor. marco.garcia@unifal-mg.edu.br.
} 
The Atlantic Forest corresponds to the second largest mass of tropical forests in South America, extending in narrow bands along the entire east coast of Brazil and in the southeast and south of the country (NEVES et al., 2017; OLIVEIRA-FILHO; FONTES, 2000; RIBEIRO et al., 2009; TABARELLI et al., 2005). It is an area of great biological diversity with high levels of endemism, being classified as a priority area for the conservation of biodiversity and tropical ecosystem services (JOLY et al., 2014; MYERS et al., 2000; TABARELLI et al., 2005). However, due to the ancient occupation and the different economic cycles to which it was subjected, it is currently concentrated in small fragments (REZENDE et al., 2018; RIBEIRO et al., 2009). It is estimated that the Atlantic Forest has only $7.6 \%$ of its original extension, which represents $98,800 \mathrm{~km}^{2}$ (MORELLATO; HADDAD, 2006), with more than $80 \%$ concentrated in small fragments of up to 50 ha (RIBEIRO et al., 2009). It is a worrying situation due to the possibility of compromising the provision of ecosystem services, considering that about two-thirds of the population and the country's gross domestic product (GDP) are concentrated in the region (JOLY et al., 2014; REZENDE et al., 2018).

Considering the entire conservation context of the Atlantic domain, efforts have been made to build knowledge that can assist in the restoration of its ecosystems (JOLY et al., 2014; SCARANO; CEOTTO, 2015). There is a huge environmental liability in the region, in areas that have been subjected to past economic activities related to various sectors of the economy, such as agribusiness, forestry production, mining, among others (REZENDE et al. , 2018; TABARELLI et al., 2005). Such restoration contexts offer different challenges and possibilities, in which certain regions have liabilities related to rural properties, while others are more related to mining activity (JOLY et al., 2014; REZENDE et al., 2018). The impacts carried out in each of the activities will determine the local characteristics, depending on the impacting agent (cattle, soil removal etc.), which will be crucial to think about the strategies to be implemented so that the success of the restoration is enhanced (CHAZDON, 2014).

Within the domain, there is still a high heterogeneity of environmental, social, and economic conditions, which will determine directions, difficulties, and opportunities for environmental conservation (NEVES et al. , 2017). The northern coastal region of the state of São Paulo is associated with the remarkable presence of the Serra do Mar in all its extension, which has been a natural barrier to the urban expansion of cities close to the region. This context hindered the region's relations with the others present in the state, which contributed to the partial preservation of forests, with some conservation units such as the "Trecho da Serra" in the city of São Sebastião, which is the focus of this study. However, the growth of tourism-related economic activities plus ports and maritime activities resulted in higher labor demand, increasing migration to the region (MARANDOLA JR et al., 2013). Thus, the occupation of the naturally unstable slopes of the Serra do Mar, without adequate protection works, led to the emergence of risk areas.

In this region, restoration activities are associated with areas that have suffered past mining activities, with areas with rugged relief that hinder even alternative land uses. Thus, studies are needed to build knowledge related to the region's vegetation that can serve as a basis for efficient and effective restoration activities. Studies are needed that explore the floristic composition of the region, as well as the ecological strategies present and that condition success, so that possible interventions can be planned to reach stages closer to restoration. (CHAZDON, 2014).

In this sense, the objective of the study was to evaluate the arboreal patterns in a 0.111 ha fragment around a 4.8 ha clearing in an area of Atlantic Forest in the city of São Sebastião/SP. This work aims to offer knowledge about the regional vegetation, which can be supported by the environmental recovery of the adjacent degraded areas. 


\section{Materials and methods}

\section{Study area}

The study site is in the municipality of São Sebastião, southeast of São Paulo state on its north coast. It occupies approximately $410 \mathrm{~km}^{2}$, of which about $70 \%$ are in Serra do Mar state park. It is limited to the north with the municipality of Caraguatatuba, west-northwest with Salesópolis, and west with Bertioga (GARCIA, 2005). It is bathed by the Atlantic Ocean throughout the south and east-northeast sector by the São Sebastião Channel (FIGURE 1). The area is located near an Atlantic Forest fragment with 4,8 hectares, where the original vegetation was composed of a dense ombrophilous forest (JOLY et al., 2012). Nowadays the fragment is covered by pastures surrounded by native vegetation, both in the lateral and upstream slopes, where are the highest altitudes.

Figure 1 - The figure indicates the location of the city of São Sebastião in the State of São Paulo, as well as the study area within the municipality. Points A refers to "Serra do DOM" and point B represents "Praia da Enseada".
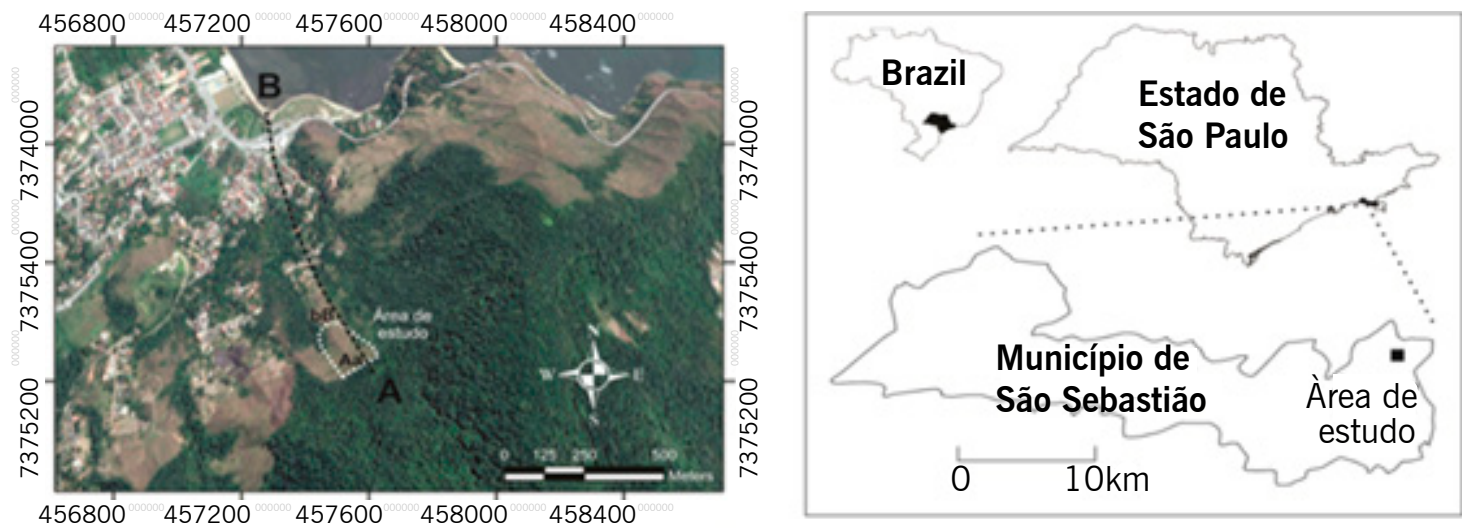

Source: Elaborated by the authors (2020).

The beginning of fragmentation and opening of areas for agricultural and urban exploration in the region began about 40 years ago slowly and gradually, by the residents themselves with the palm exploitation, the extract of wood for construction and daily use and also for the occupation for subsistence agriculture. Nowadays, the native population is aware of the importance of ecological balance, as they have noticed large differences in the environment after vegetation removal, being water scarcity one of the major concerns, as local supplies are largely linked to the springs that surround the area.

Pereira and Nunes (1997), analyzing data from 25 years (1970-1994), made the rainfall compartmentalization of the municipality of São Sebastião/SP. The study area, according to the survey of the above-mentioned authors, is located where the annual average rainfall is about 1,702.0 mm.

\section{Data collection and analysis}

The Point-Centered Quarter Method (PCQM) was used for the elaboration of the vegetal recomposition model of the clearing, data were obtained through the floristic inventory. The PCQM has been often used to sample plant communities, particularly forests (BRITO et al. 2007; MOREIRA et al. 2007; RUSCHEL et al. 2009). Fifty sample points were launched in stretches of Dense Montana Ombrophylous Forest, 30 points in the closed-canopy area, 10 points in the forest edge, and 10 points near one of the area drains. Thus, it was contemplated the physiognomic variations present in the study area and its surroundings, sampling the largest number of species. The points had a minimum distance 
of 20 meters from each other, thus ensuring that the same individual was not sampled twice. In each point, the four nearest trees were included in the sample.

The main variables collected had scientific name; commercial height (visually estimated); diameter at breast height $(\mathrm{DBH})$, successional category, and dispersion syndrome. Thus, for each species were obtained: the number of individuals sampled, the number of occurrences, and basal area. The number of individuals (NI) corresponds to the number of trees of the same species sampled; The percentage over the total (200 individuals) was also calculated. The number of occurrences (NO) refers to the number of times the species occurred, considering the sample points, in this case, the percentage over the total (50 points) was also calculated. The basal area (G) is an estimator of the horizontal spatial occupation of the tree (associated with its size), and its calculation is obtained from the tree trunk diameter at $1.30 \mathrm{~m}$ from the ground. The basal area presented by species refers to the sum of its individuals and the percentage over the total was calculated.

For the evaluation of phytosociological parameters (MÜELLER-DOMBOIS; ELLENBERG, 1974), it was estimated the basal area $(G)$ of the sampled area, absolute density (DA) and relative density (DR), relative frequency (FR), absolute dominance (DoA) and relative dominance (DoR) and value of importance (VI). The estimation of the ecological importance of families in the studied ecosystem was made by their relative density and dominance (MORI; BOOM, 1983) and the cover value (VC) highlighting the ecological importance of species in terms of distribution, based on density and dominance. For these analyzes, the Microsoft Excel for Windows program was used.

\section{Results and discussion}

We sampled 200 individuals, distributed in 28 families, 55 genera, and 71 tree species. The families with the highest species richness were: Myrtaceae (14 species), Fabaceae ( 8 species), and Lauraceae (6 species), totaling $38.4 \%$ of the sampled species (TABLE 1). The non-pioneer species was the most representative successional category, with 54 species ( $76 \%$ ), while the pioneers are represented by 17 species ( $24 \%$ ) (TABLE 1 ). The Zoochoric dispersion syndrome is the most common with 60 species (84.5\%), while Anemochoric dispersion syndrome is represented by 11 species ( $15.5 \%$ ) (TABLE 1 ).

Table 1 - List of families and tree species found in the survey, as well as their popular name, succession category, and dispersion syndrome (Zoochoric or Anemochoric).

\begin{tabular}{lllcl}
\hline Family & Scientific name & Popular name & $\begin{array}{c}\text { Successional } \\
\text { Category* }\end{array}$ & $\begin{array}{l}\text { Dispersion } \\
\text { Syndrome }\end{array}$ \\
\hline Annonaceae & Duguetia lanceolata A.St.-Hil & Araticum & $\mathrm{P}$ & Zoochoric \\
Annonaceae & Guatteria australis A.St.-Hil & Pindaíba & NP & Zoochoric \\
Annonaceae & Rollinia sericea & Araticum & NP & Zoochoric \\
Arecaceae & Bactris setosa Mart. & Tucum & NP & Zoochoric \\
Arecaceae & Euterpe edulis Mart. & Palmito Jussara & NP & Zoochoric \\
Asteraceae & Vernonia discolor (Spreng.) H.Rob. Vassourão & $\mathrm{P}$ & Anemochoric \\
Bignoniaceae & Jacaranda micrantha Cham. & Jacarandá & NP & Anemochoric \\
Bignoniaceae & Tabebuia cassinoides (Lam.) DC. & Caixeta & $\mathrm{P}$ & Anemochoric \\
Caricaceae & Jacaratia spinosa (Aubl.) DC. & Fruta-de-Veado & $\mathrm{P}$ & Zoochoric \\
Chrysobalanaceae & Licania hoehnei Pilg. & Licania & $\mathrm{NP}$ & Zoochoric \\
\hline
\end{tabular}


Table 1 - Continuation.

\begin{tabular}{|c|c|c|c|c|}
\hline Family & Scientific name & Popular name & $\begin{array}{c}\text { Successional } \\
\text { Category* }\end{array}$ & $\begin{array}{l}\text { Dispersion } \\
\text { Syndrome }\end{array}$ \\
\hline Chrysobalanaceae & Licania sp. & Licania & NP & Zoochoric \\
\hline Euphorbiaceae & $\begin{array}{l}\text { Alchornea glandulosa } \\
\text { Poepp. \& Endl. }\end{array}$ & Tapiá & $P$ & Zoochoric \\
\hline Lauraceae & Licaria armeniaca (Nees) Kosterm. & Canela & NP & Zoochoric \\
\hline Lauraceae & Nectandra grandiflora (Nees) & Canela-Amarela & NP & Zoochoric \\
\hline Lauraceae & $\begin{array}{l}\text { Nectandra membranacea (Sw.) } \\
\text { Griseb. }\end{array}$ & Canela & NP & Zoochoric \\
\hline Lauraceae & Nectandra oppositifolia Nees & Canela-Ferrugem & NP & Zoochoric \\
\hline Lauraceae & Nectandra puberula (Schott) Nees & Canela-Branca & NP & Zoochoric \\
\hline Lauraceae & Ocotea dispersa (Nees \& Mart.) Mez & Canela-Sabão & NP & Zoochoric \\
\hline Lecythidaceae & Cariniana legalis (Mart.) Kuntze & Jequitibá & NP & Anemochoric \\
\hline Fabaceae & Albizia hassleri (Chodat) Burkart & farinha-seca & $P$ & Anemochoric \\
\hline Fabaceae & Dah/stedtia pinnata (Benth.) Malme & Timbó & NP & Anemochoric \\
\hline Fabaceae & Holocalyx balansae Micheli & $\begin{array}{l}\text { Alecrim-de- } \\
\text { Campinas }\end{array}$ & NP & Anemochoric \\
\hline Fabaceae & Hymenaea sp. & Jatobá & NP & Zoochoric \\
\hline Fabaceae & Inga edwalli (Harms) T.D.Penn & Ingá & $P$ & Zoochoric \\
\hline Fabaceae & Inga marginata Willd & Ingá & $P$ & Anemochoric \\
\hline Fabaceae & $\begin{array}{l}\text { Piptadenia gonoacantha } \\
\text { (Mart.) J.F.Macbr. }\end{array}$ & Pau-jacaré & $P$ & Anemochoric \\
\hline Fabaceae & Schizolobium parahyba (Vell.) Blake & Guapuruvu & $P$ & Anemochoric \\
\hline Magnoliaceae & Magnolia ovata (A. St. -Hill) Spreng. & Pinha-D’água & NP & Zoochoric \\
\hline Malvaceae & $\begin{array}{l}\text { Pseudobombax grandiflorum (Cav.) } \\
\text { A. Robyns }\end{array}$ & Imbiruçú & NP & Anemochoric \\
\hline Meliaceae & Guarea macrophylla Vahl & Marinheiro & NP & Zoochoric \\
\hline Meliaceae & Trichilia silvatica & Catiguá & NP & Zoochoric \\
\hline Meliaceae & Trichilia pallens C. DC. & Arco-de-Peneira & NP & Zoochoric \\
\hline Melastomataceae & Miconia latecrenata (DC.) Naudin & Pixirica & $P$ & Zoochoric \\
\hline Melastomataceae & Miconia sp. & Pixirica & $P$ & Zoochoric \\
\hline Melastomataceae & $\begin{array}{l}\text { Tibouchina estrellensis } \\
\text { (Raddi) Cogn. }\end{array}$ & Quaresmeira & $P$ & Zoochoric \\
\hline Myristicaceae & Virola oleifera (Schott) A. C. Smith & Ucuúba & NP & Zoochoric \\
\hline Monimiaceae & Mollinedia uleana Perkins & Capixim & NP & Zoochoric \\
\hline Moraceae & Ficus enormis (Miq.) Miq. & Figueira & NP & Zoochoric \\
\hline Myrtaceae & Calypthranthes grandiflora & Murta & NP & Zoochoric \\
\hline Myrtaceae & Calyptranthes Iucida Mart. Ex DC. & Guamirim & NP & Zoochoric \\
\hline Myrtaceae & Campomanesia xanthocarpa O. Berg & Guabiroba & NP & Zoochoric \\
\hline Myrtaceae & Eugenia cerasiflora Miq. & Mamoneira & NP & Zoochoric \\
\hline Myrtaceae & Eugenia multicostata D. Legrand & Araçá-Piranga & NP & Zoochoric \\
\hline Myrtaceae & Eugenia sp. 1 & Eugênia & NP & Zoochoric \\
\hline Myrtaceae & Eugenia sp. 2 & Eugênia & NP & Zoochoric \\
\hline Myrtaceae & Eugenia veriflora & Eugênia & NP & Zoochoric \\
\hline
\end{tabular}


Table 1 - Continuation.

\begin{tabular}{|c|c|c|c|c|}
\hline Family & Scientific name & Popular name & $\begin{array}{c}\text { Successional } \\
\text { Category* }\end{array}$ & $\begin{array}{l}\text { Dispersion } \\
\text { Syndrome }\end{array}$ \\
\hline Myrtaceae & Gomidesia sp. 1 & Ameixa-do-Mato & NP & Zoochoric \\
\hline Myrtaceae & Gomidesia sp. 2 & Ameixa-do-Mato & NP & Zoochoric \\
\hline Myrtaceae & Marlierea parviflora O. Berg & - & NP & Zoochoric \\
\hline Myrtaceae & Myrcia cf. pubipetala Miq. & Goiabão & NP & Zoochoric \\
\hline Myrtaceae & Myrcia splendens (Sw.) DC. & $\begin{array}{l}\text { Guamirim-de- } \\
\text { folha Fina }\end{array}$ & NP & Zoochoric \\
\hline Nyctaginaceae & Guapira opposite (Vell.) Reitz & Maria-Mole & NP & Zoochoric \\
\hline Phyllanthaceae & Hyeronima alchorneoides Allemão & Aricurana & NP & Zoochoric \\
\hline Piperaceae & Piper miquelianum DC. & - & NP & Zoochoric \\
\hline Piperaceae & Piper sp. & & NP & Zoochoric \\
\hline Rubiaceae & $\begin{array}{l}\text { Alibertia myrciifolia } \\
\text { Spruce ex K. Schum }\end{array}$ & Garapatica & NP & Zoochoric \\
\hline Rubiaceae & $\begin{array}{l}\text { Coussarea contracta (Walp.) } \\
\text { Müll. Arg. }\end{array}$ & - & NP & Zoochoric \\
\hline Rubiaceae & Psychotria mapourioides DC & - & NP & Zoochoric \\
\hline Rubiaceae & Rudgea sp. & - & NP & Zoochoric \\
\hline Rutaceae & $\begin{array}{l}\text { Conchocarpus fontanesianus } \\
\text { (a. St. -Hill.) Kallunki \& Pirani }\end{array}$ & - & NP & Zoochoric \\
\hline Rutaceae & Pilocarpus sp. & Jaborandi & NP & Zoochoric \\
\hline Salicaceae & Casearia sylvestris Sw. & Guaçatonga & $P$ & Zoochoric \\
\hline Sapindaceae & $\begin{array}{l}\text { Allophylus edulis (A. St. -Hill., } \\
\text { Cambess. \& A. Juss.) Radlk }\end{array}$ & Chau-Chau & NP & Zoochoric \\
\hline Sapindaceae & Cupania oblongifolia Mart. & Cuvatã & NP & Zoochoric \\
\hline Sapotaceae & Chrysophyllum inornatum Mart. & Aguaí & NP & Zoochoric \\
\hline Sapotaceae & Ecclinusa ramiflora Mart. & Uacá & NP & Zoochoric \\
\hline Sapotaceae & Pouteria sp. & - & NP & Zoochoric \\
\hline Solanaceae & Solanum argenteum Dun. Ex Poir & Solanum Prata & $P$ & Zoochoric \\
\hline Solanaceae & Solanum pseudoquina A. St. -Hill & Joá-de-Árvore & $P$ & Zoochoric \\
\hline Symplocaceae & Symplocos celastrinea Mart. & & NP & Zoochoric \\
\hline Urticaceae & Urera baccifera (L.) Gaudich & Urtiga & $P$ & Zoochoric \\
\hline
\end{tabular}

*NP: Non-pioneer species. P: Pioneer species

Source: Elaborated by the authors (2020).

The main families found are very characteristic for forests in the state of São Paulo, however the richness varies according to the formation, degree of disturbance, and stratum. Joly et al. (2012) in a study on floristics and phytosociology in permanent plots of the Atlantic Forest also found that, in an area of dense montane forest, the families with the largest number of species were Myrtaceae, Fabaceae, Rubiaceae, and Lauraceae. Fabaceae and Lauraceae are typical of the canopy and emergent; Rubiaceae, Myrtaceae, and Melastomataceae are prominent in the understory; Euphorbiaceae and Sapindaceae participate in both strata; and Solanaceae is frequent in disturbed areas, in forest edges (MANTOVANI, 1993). According to Padgurschi et al. (2011), several studies show a high density of these families in the Montana Atlantic Forest (DIAS, 2005; GUILHERME et al., 2004; MANTOVANI, 1993; OLIVEIRA-FILHO; FONTES, 2000; ROBIM et al., 1990; TABARELLI; MANTOVANI, 1999) being, therefore, characteristics of this phytophysiognomy. 
The results found greater participation of non-pioneer and zoochoric species indicate a high stage of conservation of the fragment, which is in accordance with the conservation status of the region. The largest number of non-pioneers plants to an advanced silvigenic stage, in which species characteristic of high successional stages are composing the community (OLDEMAN, 1983). The higher proportion of zoochoric indicates the participation of biotic agents in the ecological patterns of the landscape, as they act in the seed's dispersion (BUDKE et al., 2005; CARVALHO et al., 2010). This participation is probably also related to the conservation status of the region, which has conservation units that shelter native fauna.

Among the sampled species, Guapira oppositte (Vell.) Reitz showed a higher value of VI and consequently greater sociological importance, mainly due to their higher basal area and density values compared to other species. However, when analyzing the parameters of Schizolobium parahyba (Vell.) Blake, the third species in $\mathrm{VI}$, it is noted that the superior value obtained for basal area indicates the sociological dominance of this species, even though it has a low relative density $(1.5 \%)$ and relative frequency $(1.9 \%)$ (TABLE 2$)$.

Table 2 - Distribution of the 20 species with the highest importance in the Importance Value (VI) in the sampled area.

\begin{tabular}{|c|c|c|c|c|c|c|c|c|}
\hline Species & $\mathrm{NI} *$ & NO* & G* & $\mathrm{DR}^{*}$ & FR* & DoR* & VC* & $\mathrm{VI}^{*}$ \\
\hline Guapira opposite (Vell.) Reitz & 20 & 15 & 0,352 & 10 & 9,5 & 4,94 & 24,4 & 24,43 \\
\hline Nectandra puberula (Schott) Nees & 6 & 5 & 0,832 & 3 & 3,2 & 11,7 & 17,8 & 17,83 \\
\hline Schizolobium parahyba (Vell.) Blake & 3 & 3 & 1,006 & 1,5 & 1,9 & 14,1 & 17,5 & 17,51 \\
\hline Guatteria austrails A.St.-Hil & 8 & 3 & 0,741 & 4 & 1,9 & 10,4 & 16,3 & 16,29 \\
\hline Piptadenia gonoacantha (Mart) J.F.Macbr & 7 & 5 & 0,496 & 3,5 & 3,2 & 6,95 & 13,6 & 13,61 \\
\hline Trichilia pallens C. DC. & 11 & 6 & 0,109 & 5,5 & 3,8 & 1,53 & 10,8 & 10,83 \\
\hline Symplocos celastrinea Mart. & 6 & 4 & 0,342 & 3 & 2,5 & 4,79 & 10,3 & 10,32 \\
\hline Ficus enormis (Miq.)Miq. & 1 & 1 & 0,58 & 0,5 & 0,6 & 8,14 & 9,27 & 9,27 \\
\hline Eugenia sp. 2 & 4 & 4 & 0,311 & 2 & 2,5 & 4,37 & 8,9 & 8,9 \\
\hline Guarea macrophylla Vahl & 8 & 5 & 0,09 & 4 & 3,2 & 1,26 & 8,42 & 8,42 \\
\hline Calypthrantes grandiflora & 5 & 4 & 0,112 & 2,5 & 2,5 & 1,57 & 6,6 & 6,6 \\
\hline Tabebuia cassinoides (Lam.)DC. & 5 & 5 & 0,041 & 2,5 & 3,2 & 0,58 & 6,24 & 6,24 \\
\hline Talauma ovata & 5 & 3 & 0,07 & 2,5 & 1,9 & 0,98 & 5,37 & 5,38 \\
\hline Solanum pseudoquina A. St. -Hill & 3 & 2 & 0,168 & 1,5 & 1,3 & 2,35 & 5,12 & 5,12 \\
\hline Pseudobombax grandiflorum (Cav.) A. Robyns & 4 & 4 & 0,033 & 2 & 2,5 & 0,47 & 5 & 5 \\
\hline Hymenaea sp. & 4 & 4 & 0,029 & 2 & 2,5 & 0,4 & 4,94 & 4,93 \\
\hline Solanum argenteum Dun. Ex Poir & 4 & 3 & 0,048 & 2 & 1,9 & 0,67 & 4,57 & 4,57 \\
\hline Hyeronima alchorneoides Allemão & 2 & 2 & 0,158 & 1 & 1,3 & 2,21 & 4,48 & 4,48 \\
\hline Trichila silvatica & 3 & 3 & 0,072 & 1,5 & 1,9 & 1,01 & 4,41 & 4,41 \\
\hline Marlierea parviflora O. Berg & 3 & 3 & 0,071 & 1,5 & 1,9 & 1 & 4,4 & 4,4 \\
\hline
\end{tabular}

*NI: Number of individuals; NO: Number of occurrences; G: Basal area; DR: relative density; DoR: relative dominance; VC: Cover value; VI: value of importance.

Source: Elaborated by the authors (2020).

The importance of species is related to density, frequency, and dominance values (LAMPRECHT, 1990). High values of these three parameters represent the most important species when only the community structure is evaluated. However, species with low density, but high frequency and 
dominance represent dominant and isolated trees, in small numbers, but scattered with some regularity over relatively large areas. Basal area (G) may be an important indicator of the degree of the degradation of the area. Ramos et al. (2011) associated the low values of basal area to several anthropic factors that cause disturbances in these places. While higher values are related to a better conservation status (KURTZ; ARAÚJO, 2000; MORENO et al., 2003; SZTUTMAN; RODRIGUES, 2002). According to Table 2, it is observed that the species Schizolobium parahyba (Vell.) Blake. was the one with the highest basal area value when compared to the others.

The relevant numerical data that may support the plant recomposition project are the number of individuals per species, the number of occurrences of the species at the sampling points (frequency), and the value of importance. Arruda and Daniel (2007) state that phytosociological studies can constitute a theoretical basis to assist in the preservation and use of flora resources, contributing to the recovery of degraded sites.

\section{Conclusion}

The results indicate a higher proportion of non-pioneer species, with Guapira oppositte (Vell.), presenting the highest value of importance and density, and the Schizolobium parahyba (Vell.) Blake with the highest values of basal area.

The survey data indicate the richness of species in the study area, serving as a basis for strategies for management and conservation of the environment. Phytosociological studies, although scarce, are important to support the analysis of preservation and the use of nature.

\section{Comunidade arbórea em um fragmento de encosta de Mata Atlântica em São Sebastião/SP}

\section{Resumo}

A expansão urbana e o crescimento das atividades econômicas associadas ao turismo, somadas às portuárias e marítimas, resultaram na ocupação das vertentes da Serra Mar, no município de São Sebastião/SP, aumentando a degradação ambiental. O objetivo do estudo foi avaliar o padrão arbóreo em um fragmento de 0,111 ha ao redor de uma clareira de 4,8 ha, localizado na Mata Atlântica na cidade de São Sebastião/SP, permitindo que o plano de revegetação inclua espécies nativas observadas na região. A análise fitossociológica foi feita utilizando o método de quadrantes centrados, por meio da amostragem de 50 pontos (30 em áreas próximas, 10 em áreas de borda e 10 próximas a uma das áreas de drenagem), havendo uma distância mínima de 20 metros entre elas. Foi ainda observado o número de indivíduos de cada espécie, bem como sua área basal (G), densidade relativa e absoluta (DR e DA) e dominância relativa e absoluta (DoA e DoR), frequência relativa $(\mathrm{FR})$ e o valor de importância $(\mathrm{VI})$. Os resultados indicaram uma maior proporção de espécies não pioneiras, sendo a Guapira oppositte (Vell.) com os maiores valores de importância e densidade, e a Schizolobium parahyba (Vell.) Blake com a maior área basal. Os dados analisados demonstram a riqueza de espécies na área de estudo, servindo como base para estratégias de manejo e conservação do meio ambiente. Estudos fitossociológicos, embora escassos, são importantes para subsidiar análises de preservação e de uso da natureza.

Palavras-chave: Degradação. Meio ambiete. Fitossociologia. Recomposição. 


\section{References}

ARRUDA, L.; DANIEL, O. Floristics and diversity in a seasonal alluvial semideciduous forest fragment in Dourados, MS (Portuguese). Revista Floresta, v. 37, p. 187-199, 2007. Avaliable at: https://revistas. ufpr.br/floresta/article/view/8649/6006. Access on: 12 dec. 2019.

AZEVEDO-SANTOS, V. M.; FEARNSIDE, P. M.; OLIVEIRA, C. S.; PADIAL, A. A.; PELICICE, F. M.; LIMA Jr., D. P.; SIMBERLOFF, D.; LOVEJOY, T. E.; MAGAHÃES, A. L. B.; ORSI, M. L.; AGOSTINHO, A. A.; ESTEVES, F. A.; POMPEU, P. S.; LAURANCE, W. F.; PETRERE Jr.; MORMUL, R. P. VITUALE J. R. S. Removing the abyss between conservation science and policy decisions in Brazil. Biodiversity and Conservation, v. 26, p. 1745-1752, 2017. Available at: https://link.springer.com/article/10.1007/s10531-017-1316-x. Access on: 10 nov. 2019.

BRANCALION, P. H. S.; SCHWEIZER, D.; GAUDARE, U.; MANGUEIRA, J. R.; LAMONATO, F.; FARAH, F. T.; NAVE, A. G.; RODRIGUES, R. R. Balancing economic costs and ecological outcomes of passive and active restoration in agricultural landscapes: the case of Brazil. Biotropica, v. 48, n. 6, p. 856-867, 2016. Available at: http://lerf.eco.br/img/publicacoes/2016_Brancalion_etal_custos_ativa_passiva. Access on: 12 dec. 2019.

BRITO, A.; FERREIRA, M. Z.; MELLO, J. M.; SCOLFORO, J. R. S.; DONIZETTE, A. O.; ACERBI JR., F. W. Comparação entre os métodos de quadrantes e prodon para análises florística, fitossociológica e volumétrica. Cerne, v.13, n.4, p.399-405, 2007. Available at: https://www.redalyc.org/ pdf/744/74413408.pdf. Access on: 12 dec. 2019.

BUDKE, J. C.; ATHAYDE, E. A.; GIEHL, E. L. H.; ZÁCHIA, R. A.; EISINGER, S. M. Composição florística e estratégias de dispersão de espécies lenhosas em uma floresta ribeirinha, arroio Passo das Tropas, Santa Maria, RS, Brasil. Iheringia, v. 60, p. 17-24, 2005. Available at: https://isb.emnuvens.com. br/iheringia/article/viewFile/202/209. Access on: 25 nov. 2019.

CARVALHO, F. A. Síndromes de dispersão de espécies arbóreas de florestas ombrófilas submontanas do estado do Rio de Janeiro. Revista Árvore, v. 34, n. 6, p. 1017-1023, 2010. Available at: https://www.scielo.br/pdf/rarv/v34n6/a07v34n6.pdf. Access on: 15 nov. 2019.

CHAZDON, R. L. Second Growth: The Promise of Tropical Forest Regeneration in an Age of Deforestation. Chicago: Univ. Chicago Press, 2014. Available at: https://press.uchicago.edu/ucp/books/book/chicago/S/ bo17407876.html. Access on: 16 nov. 2019.

DIAS, A. C. Floristic composition, phytosociology, species diversity and samples methods comparison in the dense ombrophilous forest in the Carlos Botelho State Park/SP - Brazil (Portuguese), 2005, PhD thesis, University of São Paulo, São Paulo. Available at: https://teses.usp.br/teses/disponiveis/11/ 11150/tde-12052005-143829/pt-br.php. Access on: 14 nov. 2019.

GARCIA, M. A. A. Hillside Recovery (Portuguese). São Paulo: LCTE Editora, 2005.

GUILHERME, F. A. G.; MORELlATO, P. C.; ASSIS, M. A. Horizontal and vertical tree community structure in a lowland Atlantic Rain Forest, Southeastern Brazil. Revista Brasileira de Botânica, v. 27, 
p. 725-737, 2004. Available at: http://www.scielo.br/scielo.php?script=sci_arttext\&pid=S0100$84042004000400012 \&$ Ing=en\&nrm=iso. Access on: 16 nov. 2019.

JOLY, C. A.; ASSIS, M. A.; BERNACCI, L. C.; TAMASHIRO, J. Y.; CAMPOS, M. C. R.; GOMES, J. A. M. A.; LACERDA, M. S.; SANTOS, F. A. M.; PEDRONI, F.; PEREIRA, L. S.; PADGURSCHI, M. C. G.; PRATA, E. M. B.; RAMOS, E.; TORRES, R. B.; ROCHELLE, A.; MARTINS, F. R.; ALVES, L. F.; VIEIRA, S. A.; MARTINELLI, .A.; CAMARGO, P. B.; AIDAR, M. P. M.; EISENLOHR, P. V.; SIMÕES, E.; VILLANI, J. P.; BELINELLO, R. Floristic and phytosociology in permanent plots of the Atlantic Rainforest along an altitudinal gradient in southeastern Brazil (Portuguese). Biota Neotropica, v. 12, p. 123-145, 2012. Available at: http://www.scielo.br/scielo.php?script=sci_arttext\&pid=S1676$06032012000100012 \&$ Ing=en\&nrm=iso. Access on: 25 nov. 2019.

JOLY, C. A.; METZGER, J. P.; TABARELLI, M. Experiences from the Brazilian Atlantic Forest: ecological findings and conservation initiatives. New Phytologist, v. 204, n. 3, p. 459-473, 2014. Available at: https://nph.onlinelibrary.wiley.com/doi/10.1111/nph.12989. Access on: 12 dec. 2019.

KURTZ, B. C., ARAÚJO, D. S. D. Floristic composition and structure of the tree component of a stretch of Atlantic Forest at Paraíso State Ecological Station, Cachoeiras de Macacu, Rio de Janeiro, Brazil (Portuguese). Rodriguésia, v. 51, p. 69-111, 2000.

LAMPRECHT H. Forestry in the tropics: - Forest ecosystems and their tree species: possibilities and methods of sustainable use. Eschborn: Silviculture Institute of University of Göttingen, GTZ, 1990. Available at: https://agris.fao.org/agris-search/search.do?recordID=DE95R0053. Access on: 30 oct. 2019.

MANTOVANI, W. Structure and dynamics of the Atlantic Forest in Juréia, Iguape, SP (Portuguese), 1993. PhD Thesis, Institute of Biosciences, University of Sao Paulo, Sao Paulo.

MARANDOLA JR, E.; MARQUES, C.; PAULA, L. T.; CASSANELI, L. B. Urban growth and risk areas on the north coast of São Paulo (Portuguese). Revista Brasileira de Estudos de População, v. 30, p. 35-36, 2013. Available at: https://www.scielo.br/scielo.php?pid=S0102-30982013000100003\&script=sci abstract. Access on: 19 dec. 2019.

MOREIRA, L. N.; MORENO, M. R.; REDLING, J. S. H. Estrutura populacional de Senefe/dera multiflora em um trecho de borda na Mata Atlântica Estacional Semidecidual da Floresta Nacional de Pacotuba, Cachoeiro de Itapemirim, Espírito Santo. Revista Brasileira de Biociências, v. 5, n. 1, p. 669-671, 2007. Available at: http://www.ufrgs.br/seerbio/ojs/index.php/rbb/article/viewFile/680/570. Access on: 19 dec. 2019.

MORELLATO, P. C.; HADDAD, C. F. B. Introduction: The Brazilian Atlantic Forest. Biotropica, v. 32, n. 4b, p. 786-792, 2006. Available at: https://onlinelibrary.wiley.com/doi/10.1111/j.1744-7429.2000. tb00618.x. Access on: 30 nov. 2019.

MORENO, M. R.; NASCIMENTO, M. T.; KURTZ, B. C. Structure and floristic composition of tree communities in two altitudinal zones in an Atlantic forest in the Imbé Region, RJ, Brazil (Portuguese). Acta Botanica Brasilica, v. 17, p. 371-386, 2003. Available at: http://arquivos.proderj.rj.gov.br/ inea_imagens/downloads/pesquisas/PE_Desengano/Moreno_etal_2003.pdf. Access on: 06 dec. 2019. 
MORI, A. S.; BOOM, B. Ecological importance of Myrtaceae in an eastern Brazilian wet forest. Biotropica, v. $15,68-70,1983$.

MÜLLER-DOMBOIS, D.; ELLEMBERG, H. Aims and methods for vegetation ecology. New York: John Wiley \& Sons, 1974. Available at: https://www.researchgate.net/publication/259466952_Aims_ and_methods_of_vegetation_ecology. Access on: 23 nov. 2019.

MYERS, N.; RUSSEL, A. M.; CRISTINA, G. M.; FONSECA, G. A. B.; KENT, J. Biodiversity hotspots for conservation priorities. Nature, v. 403, n. 6772, p. 853, 2000. Available at: https://www.nature. com/articles/35002501. Access on: 27 oct. 2019.

NEVES, D. M.; DEXTER, K. G.; PENNINGTON, R. T.; VALENTE, A. S. M.; BUENO, M. L.; EISENLOHR, P. V.; FONTES, M. A. L.; MIRANDA, P. L. S.; MOREIRA, S. N.; REZENDE, V. L.; SAITER, F. Z.; OLIVEIRA-FILHO, A. T. Dissecting a biodiversity hotspot: The importance of environmentally marginal habitats in the Atlantic Forest Domain of South America. Diversity and Distributions, v. 23, n. 8 , p. 898-909, 2017. Available at: https://www.researchgate.net/publication/315807198_Dissecting_a_ biodiversity_hotspot_The_importance_of_environmentally_marginal_habitats_in_the_Atlantic_Forest_ Domain_of_South_America. Access on: 25 oct. 2019

OLDEMAN, R. A. A. Tropical rain forest, architecture, silvigenesis, and diversity. In: SUTTON, S. L.; WHITMORE, T. C., CHADWICK, A. C. Tropical rain forest: ecology and management. Oxford: Blackwell, 1983. p. 131-150. Available at: https://research.wur.nl/en/publications/tropical-rain-forest-architecturesilvigenesis-and-diversity. Access on: 7 nov. 2019.

OLIVEIRA FILHO, A. T., FONTES, M. A. L. Patterns of floristic differentiation among Atlantic forests in Southeastern Brazil, and the influence of climate. Biotropica, v. 32, p. 793-810, 2000. Available at: https://www.researchgate.net/publication/284702091_Patterns_of_floristic_differentiation_among_ Atlantic_Forests_in_Southeastern_Brazil_and_the_influence_of_climate. Access on: 13 jan. 2020.

PADGURCHI, M. C. G; PEREIRA, L. S.; TAMASHIRO, J. Y.; JOLY, C. A. Floristic composition and similaritie between areas of Montane Atlantic Rainforest, São Paulo, Brazil. (Portuguese), Biota Neotropica, v. 11, p. 139-152, 2011. Available at: https://www.scielo.br/scielo.php?pid=S1676$06032011000200014 \&$ script=sci_arttext. Access on: 23 jan. 2020.

PEREIRA, P. R. B.; NUNES, L. H. Rain distribution and environmental problems in the municipality of São Sebastião, State of São Paulo, Brasil. In: $6^{\text {TH }}$ MEETING OF GEOGRAPHERS OF LATIN AMERICA. Buenos Aires, 1997, p.9.

RAMOS, E.; TORRES, R. B.; VEIGA, R. F. A. V.; JOLY, C. A. Study of the arboreal component in two areas of the Submontane Rainforest in Ubatuba, São Paulo State. Biota Neotropica, v, 11, p.313-335, 2011. Available at: https://www.researchgate.net/publication/297518468_Study_of_the_arboreal_component_ in_two_areas_of_the_Submontane_Rainforest_in_Ubatuba_Sao_Paulo_State. Access on: 20 jan. 2020.

REZENDE, C. L.; SCARANO, F. R.; ASSAD, E. D.; JOLY, C. A.; METZGER, J. P.; STRASSBURG, B. B. N.; TABARELLI, M.; FONSECA, G. A.; MITTERMEIER, R. A. From hotspot to hopespot: An opportunity for the Brazilian Atlantic Forest. Perspectives in ecology and conservation, v. 16, n. 4, p. 208-214, 
2018. Available at: https://www.sciencedirect.com/science/article/pii/S2530064418301317. Access on: $15 \mathrm{dec} .2019$.

RIBEIRO, M. C; METZGER, J. P.; MARTENSEN, A. C.; PONZONI, F. J.; HIROTA, M. M. The Brazilian Atlantic Forest: How much is left, and how is the remaining forest distributed? Implications for conservation. Biological conservation, v. 142, n. 6, p. 1141-1153, 2009. Available at: http://www. conexaoambiental.pr.gov.br/sites/conexao-ambiental/arquivos_restritos/files/documento/2018-11/ ribeiro_2009_biological-conservation.pdf. Access on: 28 nov. 2019.

ROBIM, M. J.; PASTORE, J. A.; AGUIAR, O. T.; BAITELLO, J. B. Arboreus shrubby and herbal flora of the Campos do Jordão State Park (SP). (Portuguese), Revista do Instituo Florestal, v. 2, p. 31-53, 1990. Available at: https://smastr16.blob.core.windows.net/iflorestal/2019/09/rev.-if-v2-n1-31-53. pdf. Access on: 28 nov. 2019.

RUSCHEL, A. R.; GUERRA, M. P.; NODARI, R. O. Estrutura e composição florística de dois fragmentos da floresta estacional decidual do Alto-Uruguai, SC. Ciência Florestal, v.19, p.225-236, 2009. Available at: https://www.scielo.br/pdf/cflo/v19n2/1980-5098-cflo-19-02-00225.pdf. Access on: 30 jan. 2020.

SCARANO, F. R.; CEOTTO, P. Brazilian Atlantic forest: impact, vulnerability, and adaptation to climate change. Biodiversity and Conservation, v. 24, n. 9, p. 2319-2331, 2015. Available at: http://www.lerf. eco.br/img/publicacoes/Scarano_Ceotto\%202015.pdf. Access on: 27 jan. 2020.

SOARES-FILHO, B.; RAJÃO, R.; MACEDO, M.; CARNEIRO, A.; COSTA, W.; COE, M.; RODRIGUES, H.; ALENCAR, A. Cracking Brazil's forest code. Science, v.344, p.363-364, 2014. Available at: http:// lerf.eco.br/img/publicacoes/Soares_Filho_etal_2014_artigo_Science.pdf. Access on: 19 nov. 2019.

SZTUTMAN, M.; RODRIGUES, R. R. Vegetational mosaic of contiguous forest area in a coastal plain, Campina do Encantado State Park, Pariquera-Açu, SP, SP. Revista Brasileira de Botânica, v. 25, p. 161-176, 2002. Available at: https://www.researchgate.net/publication/262664749_Vegetational_ mosaic_of_contiguous_forest_area_in_a_coastal_plain_Campina_do_Encantado_State_Park_PariqueraAcu_SP. Access on: 18 jan. 2020.

TABARELLI, M.; MANTOVANI, W. The richness of tree species in the Atlantic hillside forest in the state of São Paulo (Brazil) (Portuguese). Revista Brasileira de Botânica, 25, p. 217-233, 1999.

TABARELLI, M.; PINTO, L. P.; SILVA, J. M. C.; HORTA, M.; BEDÊ, L. Challenges and opportunities for biodiversity conservation in the Brazilian Atlantic Forest. Conservation Biology, v. 19, n. 3, p. 695-700, 2005. Available at: http://arquivos.proderj.rj.gov.br/inea_imagens/downloads/pesquisas/ Tabarelli_etal_2005.pdf. Access on: 16 dec. 2019.

Submitted: March 16, 2020.

Accepted: July 09, 2020. 